\title{
Application of Pollution Indices in the Assessment of Heavy Metal Contamination of Surface Sediments of River Bonsa, Ghana
}

\author{
Francis Krampah', Samuel Yeboah Nyarko², Kennedy Danlogo ${ }^{1}$, Peter Sanful ${ }^{3}$ \\ ${ }^{1}$ University of Mines and Technology, Tarkwa, Ghana \\ ${ }^{2}$ Cranfield University, Bedfordshire, UK \\ ${ }^{3}$ University of Energy and Natural Resources, Sunyani, Ghana \\ Email: franciskrampah@yahoo.co.uk
}

How to cite this paper: Krampah, F., Nyarko, S. Y., Danlogo, K., \& Sanful, P. (2019). Application of Pollution Indices in the Assessment of Heavy Metal Contamination of Surface Sediments of River Bonsa, Ghana. Journal of Geoscience and Environment Protection, 7, 176-189.

https://doi.org/10.4236/gep.2019.72012

Received: December 28, 2018

Accepted: February 25, 2019

Published: February 28, 2019

Copyright (๑) 2019 by author(s) and Scientific Research Publishing Inc. This work is licensed under the Creative Commons Attribution International License (CC BY 4.0).

http://creativecommons.org/licenses/by/4.0/

\begin{abstract}
Heavy metal contamination of sediments is a major risk to ecological systems and human health. Not only do sediments influence the quality of the water column, but can be transferred to micro biota and fishes, ultimately ending up at higher trophic levels in the food chain though biomagnification. This study was carried out to assess the contamination levels of heavy metals in the sediments of river Bonsa. Ten sediment samples were taken along the river and analyzed for Copper $(\mathrm{Cu})$, Lead $(\mathrm{Pb})$, Manganese $(\mathrm{Mn})$, Iron $(\mathrm{Fe})$, Zinc (Zn), Cadmium (Cd), Chromium (Cr), Cobalt (Co), and Nickel (Ni) using Atomic Absorption Spectroscopy (AAS). Data analysis was accomplished by comparing the measured heavy metal concentrations to Australian and New Zealand Environment and Conservation Council (ANZECC) and National Oceanic and Atmospheric Administration (NOAA) fresh water sediment quality guidelines and by the computation of geo-accumulation indices and enrichment factors. The results show that apart from Ni which had two of its sample concentrations (at BS1 $21.167 \mathrm{mg} / \mathrm{kg}$ and at BS2 $29.374 \mathrm{mg} / \mathrm{kg}$ ) exceeding the ANZECC lower limit $(21 \mathrm{mg} / \mathrm{kg}$ ) guideline for fresh water sediment, all other heavy metals recorded concentrations below the lower limits of their respective ANZECC standards. Out of the 10 samples analyzed, 7 recorded $\mathrm{Mn}$ concentrations above the NOAA ARC TEL. A one-sample t-test also showed that the mean concentrations of $\mathrm{Cu}, \mathrm{Pb}, \mathrm{Cd}, \mathrm{Zn}, \mathrm{Ni}$, and $\mathrm{Cr}$ were significantly lower than their respective ANZECC threshold values and $\mathrm{Fe}$ concentration was also significantly lower than the NOAA threshold; however, there was no significant difference between Mn mean value and the corresponding NOAA guideline value. The assessment of heavy metal pollution was derived using the Enrichment Factor (EF) and geo-accumulation indices (I-geo). The computed enrichment factors indicated that all the heavy metals
\end{abstract}


except $\mathrm{Ni}$ are from natural sources (i.e., $\mathrm{EF}<1.5$ ) signifying a degree of heavy metal depletion rather than enrichment. The sources of $\mathrm{Ni}$ were attributed to domestic waste disposal into the river at sampling points BS1 and BS2 as well as run offs from a nearby auto mechanic workshop. All the metals had I-geo values between 0 and $1(0<$ I-geo $<1)$ denoting unpolluted to moderately polluted sediments. Thus, in terms of heavy metals, the river is unpolluted. These findings are very important as it shows that river Bonsa has not yet been impacted as far as heavy metals are concerned and the data gathered may serve as baseline for future studies.

\section{Keywords}

Heavy Metals, Sediment, Enrichment Factor, Geo-Accumulation Index, Pollution Indices, River Bonsa

\section{Introduction}

Heavy metal contamination of aquatic systems is currently one of the prominent environmental issues globally, and has drawn considerable attention due to their toxicity, persistence and bioaccumulation (Zahran et al., 2015; Kanchana et al., 2014; Varol \& Sen, 2012; Zhan et al., 2010). Various authors (Kanchana et al., 2014; Yang et al., 2014; Gao \& Chen, 2012; Gowd et al., 2010; Li et al., 2000; Chang et al., 1998) have reported elevated concentrations of heavy metals in different aquatic systems around the globe and their impact on ecological and human health.

All heavy metals are toxic if present in an organism in excess amount, however, some such as $\mathrm{Cu}, \mathrm{Zn}, \mathrm{Fe}, \mathrm{Cr}, \mathrm{Mg}$ are said to be micronutrients, essential in moderate quantities for metabolism of organisms. Other heavy metals including $\mathrm{Al}, \mathrm{Cd}, \mathrm{Pb}$ have no known biological importance and exhibit extreme toxicity even at trace levels (Manahan, 2005; Canli \& Atli, 2003; Sures \& Reimann, 2003).

The effects of heavy metal pollution on macro and microbiota have been documented by several researchers to include; species loss and extinction, genetic modification, retarded growth and the alteration of the electrokinetic properties of bacteria and yeasts (Uaboi-Egbennil et al., 2010; Davies et al., 2006; Mucha et al., 2003). Heavy metals may bioaccumulate in aquatic plants, fish and shellfish and may be transferred to humans through the food chain. This results in debilitating developmental, behavioral, psychological, and cognitive changes in an exposed person and sometimes death (Kanchana et al., 2014; Fagbote \& Olanipekun, 2010).

Heavy metals may be introduced into the aquatic environment through natural sources such as atmospheric deposition and geological weathering or by anthropogenic sources including municipal and industrial discharges and agricultural run-off (Savadi et al., 2015; Kanchana et al., 2014). Upon their release into the aquatic environment, heavy metals eventually become deposited in se- 
diments through physical, chemical or biological mechanisms.

Sediments are the major repository of heavy metals in aquatic systems and play a vital role in remobilization and enrichment of the overlying water column (Banerjee et al., 2017; Rodrigue et al., 2016). The concentration of heavy metals in sediments may be 3 - 5 times higher than that of the water column with the concentration being influenced by physicochemical adsorption, physical accumulation and biological uptake (Banerjee et al., 2017; El-Madani \& Hacht, 2017; Akan et al., 2010).

Besides influencing water quality, sediments serve as sources of bioavailable contaminants for micro and macro aquatic biota and hence biomagnifications in the food chains. The transfer of heavy metals from sediments to aquatic biota is well reported (Rodrigue et al., 2016; Uaboi-Egbennil et al., 2010; Mucha et al., 2003). Sediment is therefore considered a sensitive indicator for monitoring aquatic pollution and therefore vital in preventing ecological and human health risks.

River Bonsa is the largest river draining the Tarkwa-Nsuaem municipality and serves as the source of water for domestic, agricultural and industrial activities for the riparian communities. It is also the source of water drawn, treated and distributed to all homes within the Municipality by the Ghana Water Company Limited. The quality of this water source is thus essential for the general health status of the populace.

This study aimed to assess the concentration of metal contaminants, their enrichment levels and the pollution status of sediments of river Bonsa in the Western Region of Ghana.

\section{Materials and Methods}

\subsection{Study Area}

River Bonsa is located in the Tarkwa Nsuaem municipality of the Western Region of Ghana on latitude $4^{\circ} 5^{\prime \prime}$ and longitude $5^{\circ} 5^{\prime \prime}$ (Figure 1 ). The Municipality is often labeled the Hub of mining activities in Ghana because it lies on the Birimian and Tarkwaian geological formations, which are the two most economically important formations as far as mineral deposits are concerned. As such the Municipality hosts three major mining companies and many other small-scale mining companies.

\subsection{Survey and Sampling}

Before the collection of sediments samples, a survey was conducted to identify suitable sampling sites taking into account factors such as accessibility, human activities and establishments near the river.

Ten sediment samples were collected at approximately $90 \mathrm{~m}$ along the river using a grab sampler and labelled BS1 to BS10. A handheld GPS receiver was used to record the coordinates of all the sampling points as shown in Table 1. Figure 2 shows sampling points along the river Bonsa. All samples collected 
Table 1. Summary of sampling point coordinates.

\begin{tabular}{ccccccccccc}
\hline $\begin{array}{c}\text { Sampling } \\
\text { Points }\end{array}$ & BS1 & BS2 & BS3 & BS4 & BS5 & BS6 & BS7 & BS8 & BS9 & BS10 \\
\hline Long. E & 606,882 & 606,554 & 606,371 & 606,223 & 605,988 & 606,038 & 606,120 & 605,916 & 605,712 & 605,460 \\
Lat. N & 572,713 & 572,795 & 572,403 & 572,380 & 572,404 & 572,543 & 572,656 & 572,686 & 572,723 & 572,871 \\
\hline
\end{tabular}

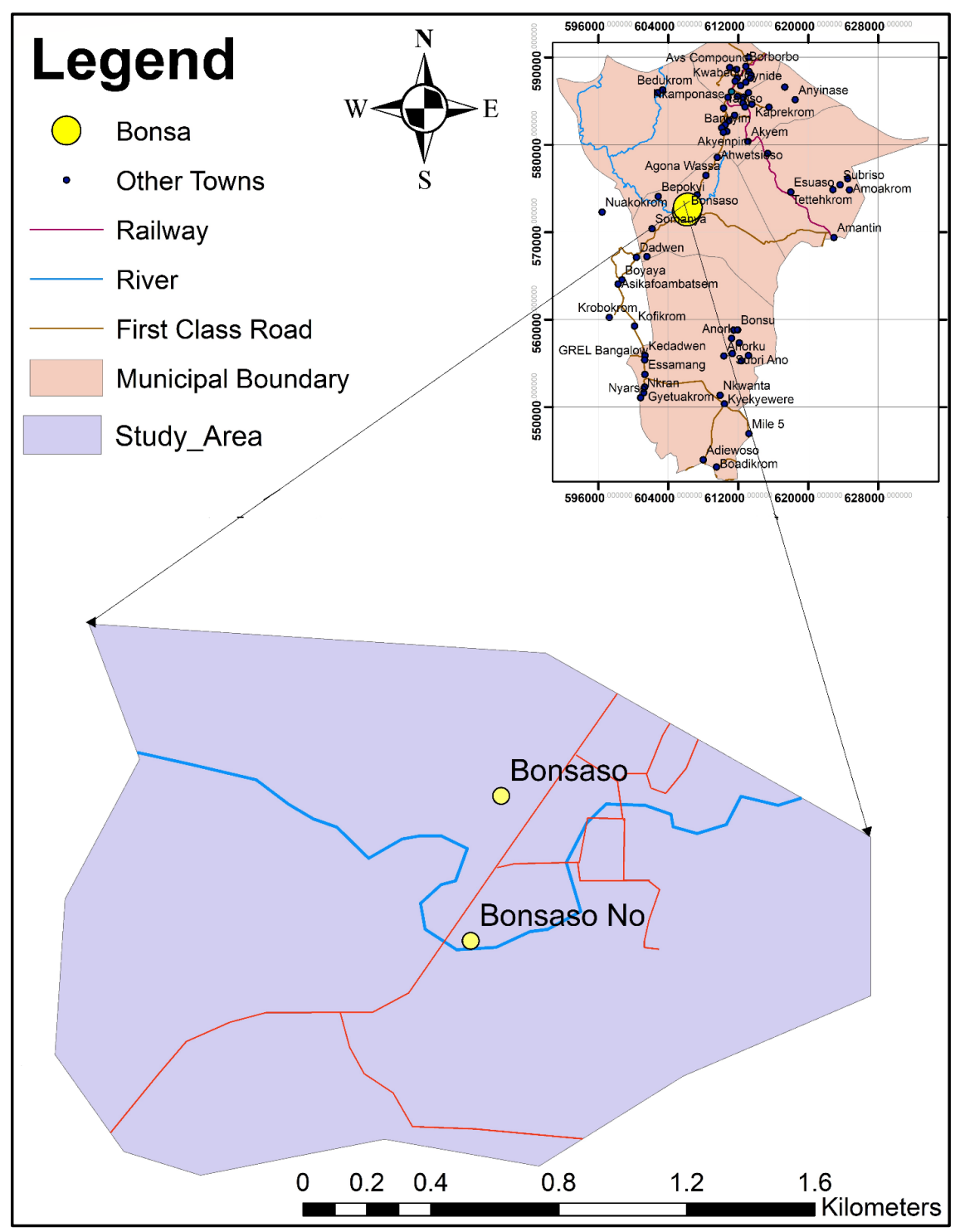

Figure 1. A map of Tarkwa showing Bonsaso (riparian community).

were stored in well labeled Ziploc bags, sealed and transported to the laboratory for pre-treatment and analyses.

\subsection{Sample Preparation}

In the laboratory, the sediment samples were oven dried at a temperature of $110^{\circ} \mathrm{C}$ for one hour to remove the moisture content. The dried samples were allowed to cool and subsequently acid digested. 


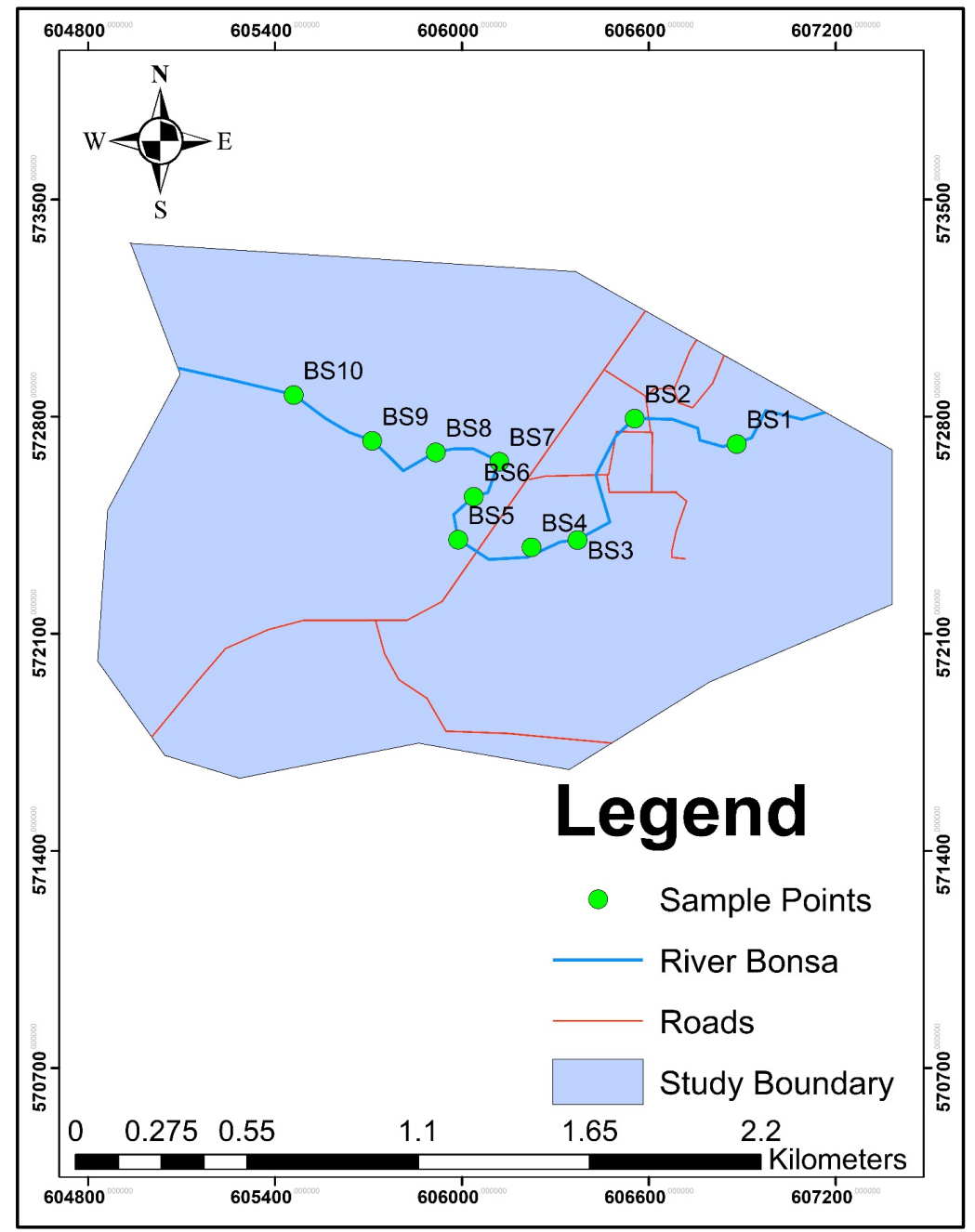

Figure 2. Map of river Bonsa showing sampling points.

\subsection{Sample Digestion}

Aqua Regia $\left(68 \%\right.$ w/w Nitric acid $\left(\mathrm{HNO}_{3}\right)$ and $35 \% \mathrm{w} / \mathrm{w}$ Hydrochloric acid $(\mathrm{HCl})$ ) in the ratio 1:3 (i.e. $10 \mathrm{~mL}$ of $\mathrm{HNO}_{3}$ and $30 \mathrm{~mL}$ of $\mathrm{HCl}$ ) was added to $5 \mathrm{~g}$ each of the dried sediment samples and heated on a hot plate at $105^{\circ} \mathrm{C}$ for 15 minutes. $10 \mathrm{~mL}$ each of the digests were transferred into $50 \mathrm{~mL}$ standard flask and topped up to the mark with distilled water. These were then filtered through $0.45 \mu \mathrm{m}$ Whatman filter paper and used for heavy metal analysis.

\subsection{Heavy Metal Analysis}

$\mathrm{Cu}, \mathrm{Cd}, \mathrm{Pb}, \mathrm{Fe}, \mathrm{Mn}, \mathrm{Ni}, \mathrm{Cr}, \mathrm{Zn}$ and $\mathrm{Co}$ were analyzed using the Varian AA240FS Fast Sequential Atomic Absorption Spectrometer (AAS) at absorbance wavelength of 324.8, 228.8, 217.0, 243.8, 279.5, 232.0, 357.9, 213.9, and $240.7 \mathrm{~nm}$ respectively. The results were then compared with the Australian and New Zealand Environment and Conservation Council (ANZECC) and National Oceanic and Atmospheric Administration (NOAA) Guidelines for fresh water sediment quality. 
The ANZECC and NOAA guidelines both have two limits, the ISQG-low concentration also known as the trigger concentration and the ISQG high concentration. The trigger concentration is the threshold below which the probability of adverse effect is very low or negligible whilst the ISQG high concentration is the limit beyond which the heavy metals become bioavailable. Exceeding this value however does not mean adverse effects will occur in the sediments, but will require further investigation into other factors that influence bioavailability to confirm whether or not an adverse effect will be produced.

\subsection{Contamination Assessment}

The study employed the geo-accumulation index (I-geo) and Enrichment Factor (EF) to determine the status and sources of heavy metal contamination of the sediments respectively.

\subsubsection{Enrichment Factor}

Enrichment is a method used to estimate the anthropogenic impact on sediments by calculating the difference between the metals originating from human activities and those from natural provenance. Enrichment factor is a means of determining anthropogenic influence on heavy metal concentration in sediments (Rodrigue et al., 2016). The EF is calculated by using Equation (1);

$$
\mathrm{EF}=\frac{(\mathrm{Cx} / \mathrm{Cref}) \text { sample }}{\left(\frac{\mathrm{Bx}}{\mathrm{Bref}}\right) \text { reference sample }}
$$

where,

$\mathrm{Cx}=$ Content of the examined element in the examined environment

$\mathrm{Cref}=$ Content of the examined element in the reference environment

$\mathrm{Bx}=$ Content of the reference element in the examined environment

$\mathrm{Bref}=\mathrm{Content}$ of the reference element in the reference environment

The contamination categories are recognized on the basis of the enrichment factor as follows:

$\mathrm{EF}<2$, Deficiency to minimal enrichment,

$\mathrm{EF}=2-5$, Moderate enrichment,

$\mathrm{EF}=5-20$, Severe enrichment,

$\mathrm{EF}=20-40$, Very high enrichment and

EF > 40, extremely high enrichment (Sutherland, 2000).

\subsubsection{Geo-Accumulation Index (I-geo)}

Index of geo-accumulation (I-geo) was originally defined by Muller in 1969, in order to define and determine metal contamination in sediments by comparing the levels of heavy metal obtained to a background level originally used with bottom sediments (Atiemo et al., 2011). It is calculated by using Equation (2);

$$
\text { Igeo }=\log 2 \frac{(\mathrm{Cx})}{1.5 \mathrm{Bref}}
$$


where,

$\mathrm{Cx}=$ Content of the examined element in the examined environment

Bref $=$ Content of the reference element in reference environment

Loska \& Wiechuya (2010), gave the following interpretation for the geo-accumulation index:

I-geo $<0=$ practically unpolluted,

$0<$ I-geo $<1=$ unpolluted to moderated polluted,

$1<$ I-geo $<2=$ moderately polluted,

$2<$ I-geo $<3=$ moderately to strongly polluted,

$3<$ I-geo $<4=$ strongly polluted,

$4<$ I-geo $<5=$ strongly to extremely polluted,

I-geo $>5=$ extremely polluted.

\section{Results and Discussion}

For effective interpretation and discussions, the result of the concentrations of the various heavy metals studied have been compared with the Australian and New Zealand Environment and Conservation Council (ANZECC) Guidelines for fresh water sediment quality. Where appropriate, the results have also been compared with the National Oceanic and Atmospheric Administration (NOAA) fresh water sediment quality guidelines. The data have been presented graphically in Figures 3-11.

\subsection{Sediment Quality Guideline}

The concentrations of zinc, lead, cadmium, chromium and copper in all the 10 samples analyzed were below their respective ANZECC trigger concentrations or threshold limits (Figures 3-8). The concentrations of iron in all the samples analyzed were found to be below its corresponding NOAA ARC TEL. This implies a very low probability of bioavailability of these metals and hence no ecological or human health impact.

With the exception of BS1 and BS2, all samples analyzed had Ni concentrations below the ANZECC trigger value (Figure 9). The Ni concentrations at BS1 and BS2 although greater than the trigger limit were all found to be well below the ISQG high concentration. The high Ni concentration at BS1 and BS2 could

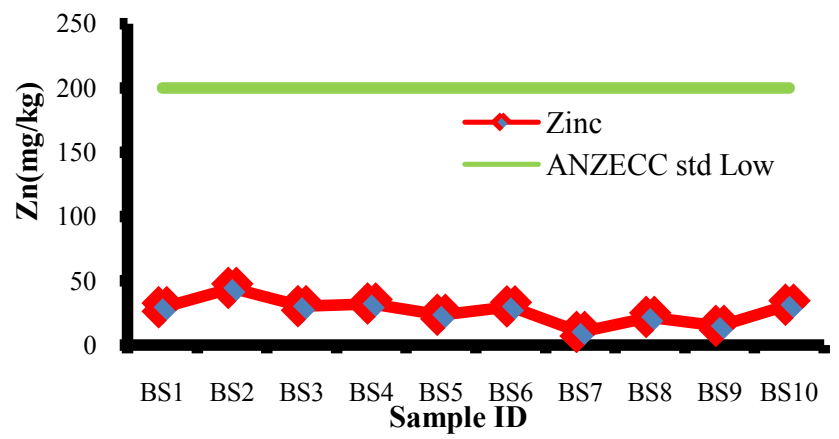

Figure 3. Zn concentrations in sediment samples. 


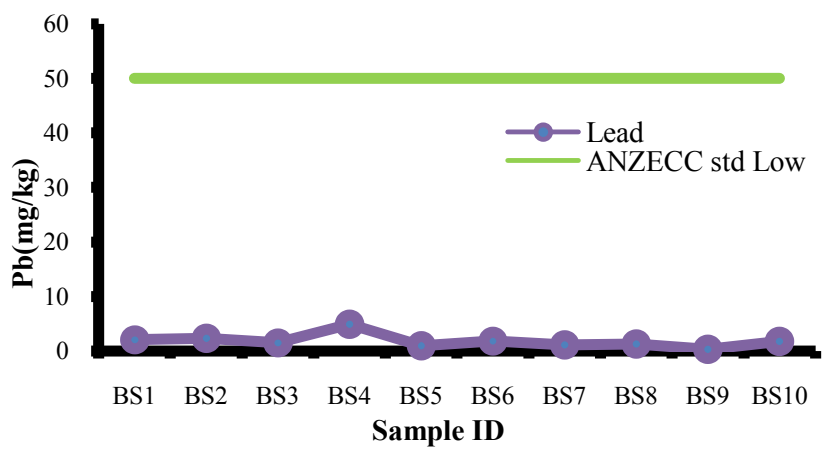

Figure 4. $\mathrm{Pb}$ concentrations in sediment samples.

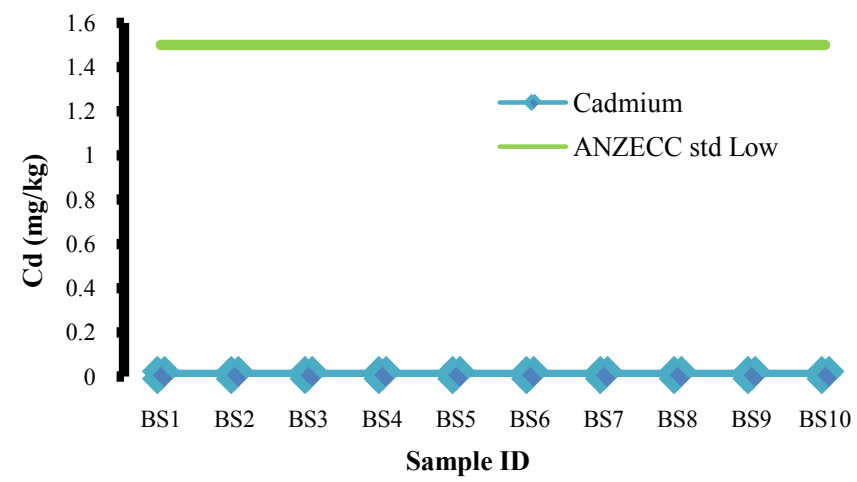

Figure 5. Cd concentrations in sediment samples.

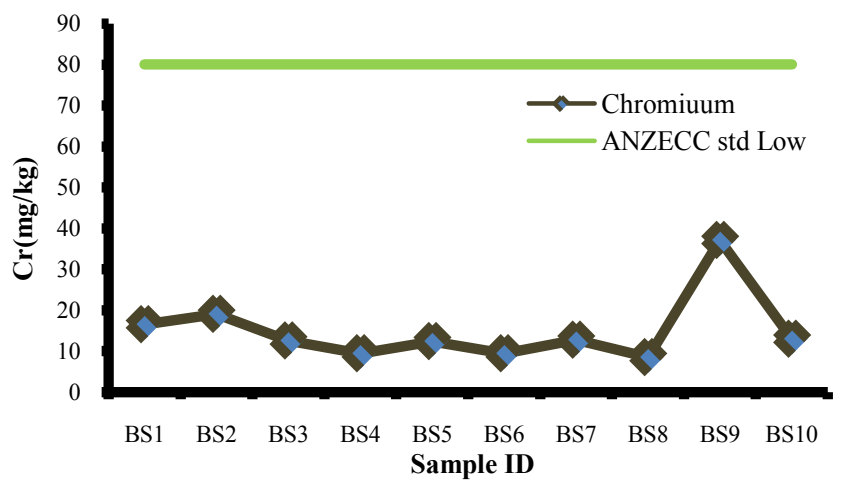

Figure 6. Cr concentrations in sediment samples.

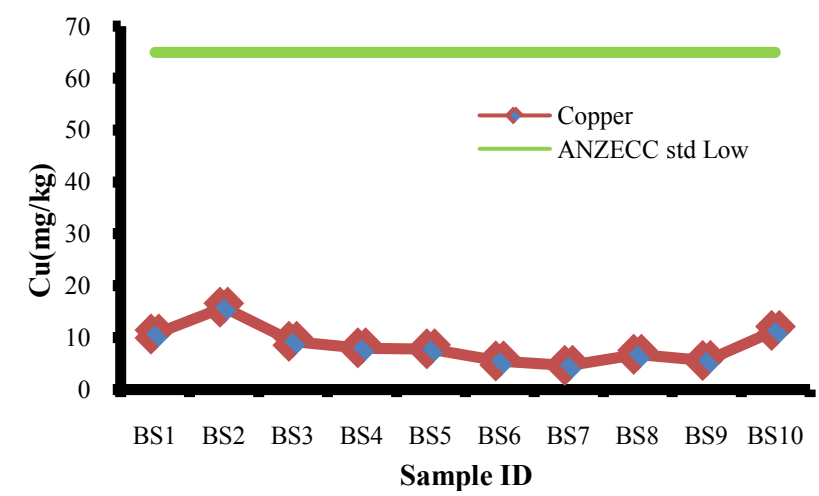

Figure 7. $\mathrm{Cu}$ concentrations in sediment samples. 


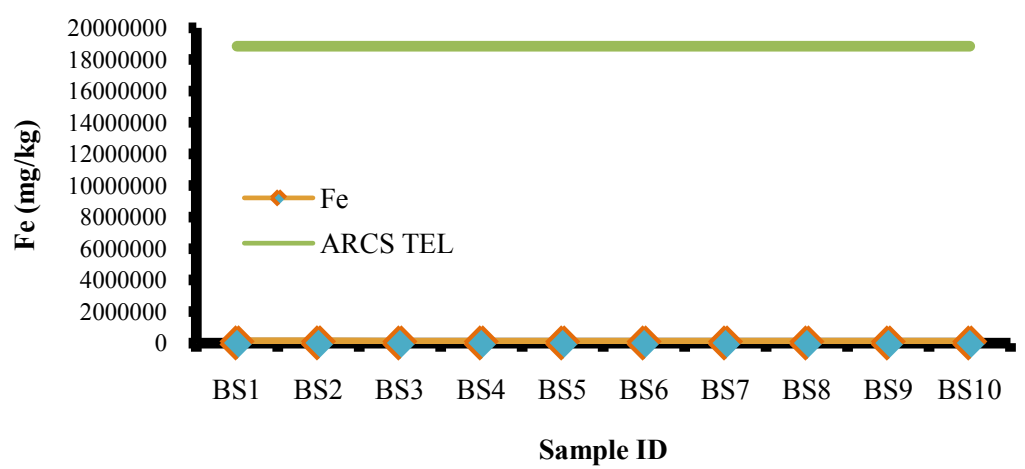

Figure 8. Fe concentrations in sediment samples.

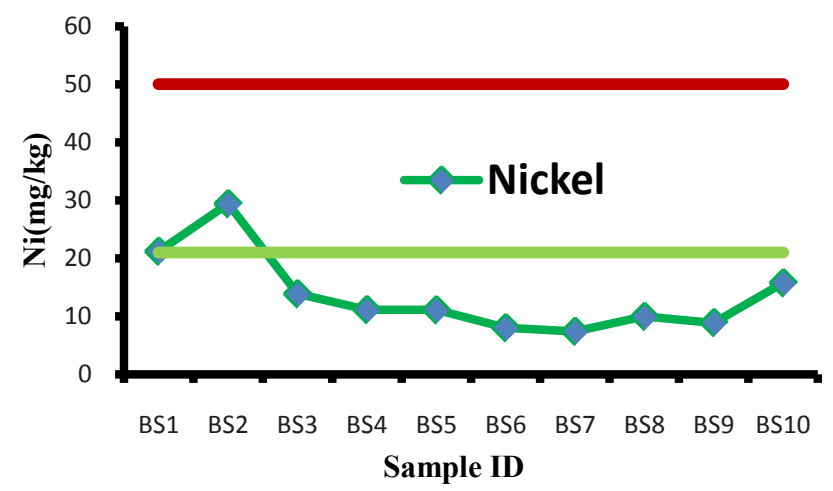

Figure 9. Ni concentrations in sediment samples.

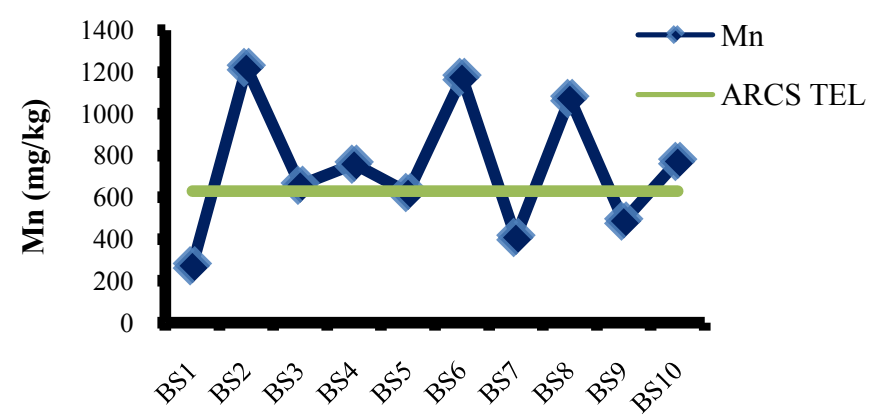

Sample ID

Figure 10. Mn concentrations in sediment samples.

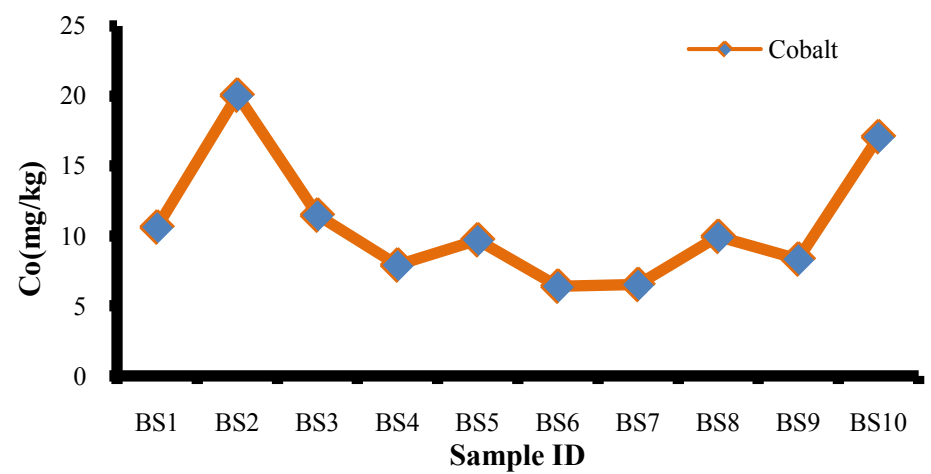

Figure 11. Cobalt concentrations in sediment samples. 
be attributed to the disposal of domestic waste into the river at sampling points BS1 and BS2. These wastes usually include batteries and other Ni containing substances (Harasim \& Filipek, 2015). The Ni concentration at BS2 could have been further enhanced by run offs from an auto mechanic workshop closely associated with BS2. Concentrations in between the low and high ISQG value do not necessarily mean adverse impact will occur. Other factors in addition, will help determine the bioavailability of the metal. More so, the average Ni concentration was found to be $13.645 \mathrm{mg} / \mathrm{kg}$, which is below the trigger value of 20 $\mathrm{mg} / \mathrm{kg}$, hence the frequency of occurrence of the adverse impact will be very low.

Mn recorded a maximum concentration of $1221.602 \mathrm{mg} / \mathrm{kg}$ at sample point BS2 and a minimum concentration of $273.216 \mathrm{mg} / \mathrm{kg}$ at BS1 (Figure 10) with an average concentration of $745.097 \mathrm{mg} / \mathrm{kg}$. Apart from BS1, BS7 and BS9, all other samples recorded Mn concentration above NOAA ARC TEL $(p<0.05)$. According to (El-Madani \& Hacht, 2017, Barceloux, 1999), about $0.1 \%$ of the earth's crust is composed of Mn. Moreover, the high Mn concentrations are as expected, as the study area is high in Mn deposits and the metal is being mined in commercial quantities, about 15.4kilometers from the river (Google Map, 2018). The high Mn concentrations are attributable to geogenic sources as was later indicated by the calculated EF (Table 3). The use of Mn gangue for construction activities in the catchment areas may have contributed to the differences in the concentration levels recorded at the different sampling points. Mn concentrations are within natural limits and will not impact human and ecological health negatively.

Cobalt had maximum and minimum concentrations of $20.039 \mathrm{mg} / \mathrm{kg}$ and $6.401 \mathrm{mg} / \mathrm{kg}$ respectively (Figure 11) with an average of $10.805 \mathrm{mg} / \mathrm{kg}$. Both ANZECC and NOAA guidelines for fresh water sediment quality do not state any value(s) for cobalt concentrations in sediments. As Co is naturally occurring, all aquatic environment contains trace concentration of this element, sometimes referred to as background concentration. Additionally, the mean concentration of $10.805 \mathrm{mg} / \mathrm{kg}$ recorded is much lower than $15.42 \mathrm{mg} / \mathrm{kg}$ mean Co concentrations recorded by (Li et al., 2018) although background concentrations differ from region to region.

\subsection{Statistical Analysis}

The mean concentrations of the various heavy metals were compared with their corresponding ANZECC or NOAA ARCS TELL threshold guideline values using a one-sample t-test as shown in Table 2. It was observed that the mean concentrations of $\mathrm{Cu}, \mathrm{Pb}, \mathrm{Cd}, \mathrm{Zn}, \mathrm{Ni}$, and $\mathrm{Cr}$ were significantly lower than their respective ANZECC threshold values $(p<0.05)$. The mean Fe concentration was also significantly lower than the NOAA threshold, however there was no significant difference between $\mathrm{Mn}$ mean value and the corresponding NOAA guideline value. However, it was close to the NOAA threshold value. These higher Mn levels corroborate the economic deposit of $\mathrm{Mn}$ in the study area. 
Table 2. One sample t-test comparison of mean heavy metal concentrations and ANZECC/ NOAA standards.

\begin{tabular}{|c|c|c|c|c|c|c|c|c|c|}
\hline Sampling locations & $\begin{array}{c}\mathrm{Cu} \\
\mathrm{Mg} / \mathrm{kg}\end{array}$ & $\begin{array}{c}\mathrm{Pb} \\
\mathrm{Mg} / \mathrm{kg}\end{array}$ & $\begin{array}{c}\mathrm{Cd} \\
\mathrm{Mg} / \mathrm{kg}\end{array}$ & $\begin{array}{c}\mathrm{Co} \\
\mathrm{Mg} / \mathrm{kg}\end{array}$ & $\begin{array}{c}\mathrm{Mn} \\
\mathrm{Mg} / \mathrm{kg}\end{array}$ & $\begin{array}{c}\mathrm{Zn} \\
\mathrm{Mg} / \mathrm{kg}\end{array}$ & $\begin{array}{c}\mathrm{Ni} \\
\mathrm{Mg} / \mathrm{kg}\end{array}$ & $\begin{array}{c}\mathrm{Cr} \\
\mathrm{Mg} / \mathrm{kg}\end{array}$ & $\begin{array}{c}\mathrm{Fe} \\
\mathrm{Mg} / \mathrm{kg}\end{array}$ \\
\hline BS1 & 10.689 & 2.05 & 0.008 & 10.62 & 273.21 & 29.493 & 21.167 & 16.56 & 7916.3 \\
\hline BS2 & 15.85 & 2.34 & 0.008 & 20.04 & 1221.6 & 44.52 & 29.37 & 19.09 & $10,116.3$ \\
\hline BS3 & 9.291 & 1.49 & 0.008 & 11.47 & 658.23 & 30.29 & 13.83 & 12.59 & 3313.67 \\
\hline BS4 & 8.035 & 4.93 & 0.008 & 7.912 & 759.07 & 32.36 & 11.11 & 9.47 & 5320.84 \\
\hline BS5 & 7.85 & 0.94 & 0.008 & 9.72 & 623.56 & 23.59 & 11.07 & 12.43 & 3591.07 \\
\hline BS6 & 5.51 & 1.81 & 0.008 & 6.4 & 1174.2 & 30.13 & 7.99 & 9.47 & 3362.29 \\
\hline BS7 & 4.667 & 1.13 & 0.008 & 6.52 & 408.33 & 10.24 & 7.37 & 12.78 & 3460.34 \\
\hline BS8 & 6.796 & 1.279 & 0.008 & 9.96 & 1073.5 & 21.92 & 9.93 & 8.52 & 2106.01 \\
\hline BS9 & 5.59 & 0.29 & 0.008 & 8.33 & 487.04 & 14.946 & 8.87 & 37.14 & 1613.55 \\
\hline BS10 & 11.38 & 1.749 & 0.008 & 17.07 & 772.22 & 31.41 & 15.73 & 13.01 & 2294.46 \\
\hline ANZECC Low std. & 65 & 50 & 1.5 & - & - & 200 & 21 & 80 & - \\
\hline ARCS TEL & - & - & - & - & 630 & - & - & - & $18,840,000$ \\
\hline Mean & 8.57 & 1.80 & 0.008 & 10.80 & 745.10 & 26.99 & 13.64 & 15.11 & 4309.48 \\
\hline Std. Error of mean & 1.07 & 0.39 & - & 1.41 & 102.47 & 3.06 & 2.18 & 2.65 & 863.20 \\
\hline$t$-statistic & -52.67 & -122.25 & - & - & 1.12 & -56.48 & -3.368 & -24.456 & $-21,820.70$ \\
\hline$d f$ & 9 & 9 & - & - & 9 & 9 & 9 & 9 & 9 \\
\hline$p$-value & 0.000 & 0.000 & - & - & 0.290 & 0.000 & 0.008 & 0.000 & 0.000 \\
\hline
\end{tabular}

\subsection{Contamination Assessment}

Based on the individual elements' measured concentrations and their background values, geo-accumulation indices and enrichment factors were calculated to determine the levels and sources of contamination, respectively, and the results are shown in Table 3.

\subsubsection{Enrichment Factor (EF)}

The EF values for all the metals except Ni analyzed were less than 1.5 which denotes no enrichment. This means all the heavy metals measured had their sources from the natural environment or geogenic source except $\mathrm{Ni}$. Ni had a calculated EF of 3.44 denoting moderate enrichment (Table 3).

\subsubsection{Geo-Accumulation Index (I-Geo)}

According to (Saleem et al., 2015), I-geo is the quantitative value of contamination index in sediments and as such any increase in the reference level may be envisaged as anthropogenic (Rodrigue et al., 2016). All the heavy metals analyzed had I-geo values between 0 and 1 which denotes unpolluted to moderately polluted. Hence the river may be said to be unpolluted with respect to heavy metals. 
Table 3. Enrichment Factor and Geo accumulation Index of the various heavy metals.

\begin{tabular}{|c|c|c|c|c|c|c|c|c|}
\hline \multirow[b]{2}{*}{ Metals } & \multirow[b]{2}{*}{$\begin{array}{l}\text { Mean Conc. } \\
(\mathrm{mg} / \mathrm{kg})\end{array}$} & \multirow[b]{2}{*}{$\begin{array}{l}\text { ANZECC Low std } \\
(\mathrm{mg} / \mathrm{kg})\end{array}$} & \multicolumn{2}{|c|}{ NOAA } & \multirow[b]{2}{*}{${ }^{2} \mathrm{EF}$} & \multirow[b]{2}{*}{${ }^{3} \mathrm{DE}$} & \multirow[b]{2}{*}{${ }^{4} \mathrm{GI}$} & \multirow[b]{2}{*}{${ }^{5} \mathrm{DI}$} \\
\hline & & & $\begin{array}{l}\text { ARCS TEL } \\
\mathrm{mg} / \mathrm{kg}\end{array}$ & $\begin{array}{c}{ }^{1} \mathrm{BG} \\
\mathrm{mg} / \mathrm{kg}\end{array}$ & & & & \\
\hline $\mathrm{Cu}$ & 8.568 & 65 & - & - & 0.698 & Depletion & 0.021 & Unpolluted to Moderately \\
\hline $\mathrm{Pb}$ & 1.804 & 50 & & - & 0.191 & Depletion & 0.0045 & Unpolluted to Moderately \\
\hline $\mathrm{Cd}$ & 0.008 & 1.5 & - & & 0.028 & Depletion & 0.00002 & Unpolluted to Moderately \\
\hline $\mathrm{Zn}$ & 26.891 & 200 & - & - & 0.712 & Depletion & 0.067 & Unpolluted to Moderately \\
\hline $\mathrm{Ni}$ & 13.646 & 21 & - & - & 3.44 & Moderate & 0.034 & Unpolluted to Moderately \\
\hline $\mathrm{Cr}$ & 15.107 & 80 & - & - & 1 & Depletion & 0.038 & Unpolluted to Moderately \\
\hline Co & 10.804 & - & - & 10 & 0.930 & Depletion & 0.2168 & Unpolluted to Moderately \\
\hline Mn & 745.096 & - & 630 & 400 & 1.503 & Depletion & 0.3738 & Unpolluted to Moderately \\
\hline $\mathrm{Fe}$ & 4309.48 & - & $18,840,000$ & $1,800,000$ & 0.002 & Depletion & 0.0004 & Unpolluted to Moderately \\
\hline
\end{tabular}

1: Background Concentration; 2: Enrichment Factor; 3: Degree of Enrichment; 4: Geo-accumulation index; 5: Degree of I-geo.

\section{Conclusion}

This study was carried out on the sediments of River Bonsa to examine the levels and sources of heavy metal contamination. ANZECC and NOAA standards for fresh water sediment quality were used as the benchmark against measured concentrations of the heavy metals in the sediments of river Bonsa. Geo-accumulation indices and enrichment factors were also calculated.

The concentrations of $\mathrm{Cu}, \mathrm{Pb}, \mathrm{Cr}, \mathrm{Cd}, \mathrm{Zn}$ and $\mathrm{Fe}$ were all below their respective trigger values. Out of the ten samples of $\mathrm{Ni}$ analyzed, two had $\mathrm{Ni}$ values above the ISQG lower limit but below the upper limit. The mean $\mathrm{Ni}$ value was below the ISQG threshold limit. Out of the 10 samples analyzed, 7 recorded Mn concentrations above the NOAA ARC TEL. Co although had no ISQG standard guideline values when compared to similar ecosystems showed no alarming conditions.

The calculated enrichment factor showed that all the heavy metals except $\mathrm{Ni}$ are from natural/geogenic sources. The sources of Ni were attributed to domestic waste disposal into the river as well as run offs from a nearby auto mechanic workshop. The pollution status of River Bonsa inferred from the calculated I-geo is unpolluted to moderately polluted. The River could be said to be unpolluted with heavy metals and may not adversely impact the health of the ecosystem or humans. However, continuous monitoring of the river sediment is required to detect future changes in the concentrations of heavy metals and their impact on aquatic ecosystem health.

\section{Conflicts of Interest}

The authors declare no conflicts of interest regarding the publication of this paper. 


\section{References}

Akan, C. J., Abdulrahman, F. I., Sodipo, O. A., Ochany, A. E., \& Askira, Y. K. (2010). Heavy Metals in Sediments from River Ngada, Maiduguri Metropolis, Borno State, Nigeria. Journal of Environmental Chemistry, 2, 131-140.

Atiemo, M. S., Ofosu G. F., Kuranchie-Mensah, H., \& Osei Tutu, A. (2011). Contamination Assessment of Heavy Metals in Road Dust from Selected Roads in Accra, Ghana. Research Journal of Environmental and Earth Sciences, 5, 473-480.

Banerjee, S., Pramanik, A., Sengupta, S., Chattopadhyay, D., \& Bhattacharyya, M. (2017). Distribution and Source Identification of Heavy Metal Concentration in Chilika Lake, Odisha India: An Assessment over Salinity Gradient. Current Science, 112, 87-94. https://doi.org/10.18520/cs/v112/i01/87-94

Barceloux, D. G. (1999). Manganese. Journal of Toxicology: Clinical Toxicology, 37, 293 307. https://doi.org/10.1081/CLT-100102427

Canli, M., \& Atli, G. (2003). The Relationships between Heavy Metal (Cd, Cr, Cu, Fe, Pb, $\mathrm{Zn})$ Levels and the Size of Six Mediterranean Fish Species. Environmental Pollution, 121, 129-136. https://doi.org/10.1016/S0269-7491(02)00194-X

Chang, J. S., Yu, K. C., Tsai, L. J., \& Ho, S. T. (1998). Spatial Distribution of Heavy Metalsin Bottom Sediment of Yenshui River, Taiwan. Water Science and Technology, 38, 159-167. https://doi.org/10.2166/wst.1998.0459

Davies, O. A., Allison, M. E., \& Uyi, H. S. (2006). Bioaccumulation of Heavy Metals in Water, Sediment and Periwinkle (Tympanotonus fuscatus var Radula) from the Elechi Creek, Niger Delta. African Journal of Biotechnology, 5, 968-973.

El-Madani, M., \& Hacht, B. (2017). Spatial Distribution and Risk Assessment of Some Heavy Metal Ions in the Surface Sediments of the Lagoon of Nador. Journal of Materials and Environmental Sciences, 8, 1996-2005.

Fagbote, E. O., \& Olanipekun, E. O. (2010). Evaluation of the Status of Heavy Metal Pollution of Soil and Plant (Chromolaena odorata) of Agbabu Bitumen Deposit Area, Nigeria. American-Eurasian Journal of Scientific Research, 5, 241-248.

Gao, X., \& Chen, C. T. A. (2012). Heavy Metals Pollution Status in Surface Sediments of the Coastal Bohai Bay. Water Research, 46, 1901-1911.

https://doi.org/10.1016/j.watres.2012.01.007

Google Map (2018). Distance from Bonsa to Ghana Manganese Company Limited.

Gowd, S. S., Reddy, R. M., \& Govil, P. K. (2010). Assessment of Heavy Metal Contamination in Soils at Jajmau (Kanpur) and Unnao Industrial Areas of the Ganga Plain, Uttar Pradesh, India. Journal of Hazardous Materials, 174, 113-121.

https://doi.org/10.1016/j.jhazmat.2009.09.024

Harasim, P., \& Filipek, T. (2015). Nickel in the Environment. Journal of Elementology, 20, 525-534. https://doi.org/10.5601/jelem.2014.19.3.651

Kanchana, C. M., Chandrasekara, N. K., Weerasinghe, K. D. N., Pathirana, S., \& Piyadasa, R. U. K. (2014). Heavy Metal Contamination of Water in Negombo Lagoon and Interconnected Water Sources. Lakes, Reservoirs and Ponds, 8, 96-110

Li, X., Wai, W. H. O., Li, Y. S., Coles, J., Barry, R. H. M., \& Thornton, I. (2000). Heavy Metal Distribution in Sediment Profiles of the Pearl River estuary, South China. Applied Geochemistry, 15, 567-581. https://doi.org/10.1016/S0883-2927(99)00072-4

Li, Y., Qu, X., Zhang, M., Peng, W., Yu, Y., \& Gao, B. (2018). Anthropogenic Impact and Ecological Risk Assessment of Thallium and Cobalt in Poyank Lake Using Geochemical Baseline. Water, 10, 1703-1718. https://doi.org/10.3390/w10111703

Loska, K., \& Wiechuya, D. (2010). Application of Principle Component Analysis for the 
Estimation of Source of Heavy Metal Contamination from Surface Sediments from the Rybnik Reservoir. Chemosphere, 51, 723-733.

https://doi.org/10.1016/S0045-6535(03)00187-5

Manahan, S. E. (2005). Environmental Chemistry (8th ed., 466 p). Boca Raton, FL: CRC Press, Taylor and Francis Group.

Mucha, A. P., Vasconcelos, M. T. S., \& Bordalo, A. A. (2003). Macrobenthic Community in the Douro Estuary: Relations with Trace Metals and Natural Sediment Characteristics. Environmental Pollution, 121, 169-180.

https://doi.org/10.1016/S0269-7491(02)00229-4

Rodrigue, K. A., Yao, B., Trokourey, A., \& Kopoin, A. (2016). Assessment of Heavy Metals Contamination in Sediments of the Vridi Canal (Cote d'Ivoire). Journal of Geoscience and Environment Protection, 4, 65-73. https://doi.org/10.4236/gep.2016.410004

Saleem, M., Iqbal, J., \& Shah, M. H. (2015). Geochemical Speciation, Anthropogenic Contamination, Risk Assessment and source Identification of Selected Metals in Fresh Water Sediments-A Case Study from Mangla Lake, Pakistan. Environmental Nanotechnology, Monitoring \& Management, 4, 27-36.

https://doi.org/10.1016/j.enmm.2015.02.002

Sures, B., \& Reimann, R. (2003). Analysis of Trace Metals in the Antarctic Host-Parasite System Notothenia coriiceps and Aspersentismegarhynchus (Acanthocephala) Caught at King George Island, South Shetland Islands. Polar Biology, 26, 680-686. https://doi.org/10.1007/s00300-003-0538-4

Sutherland, R. A. (2000). Bed Sediment-Associated Trace Metals in an Urban Stream, Oahu, Hawaii. Environmental Geology, 39, 611-637.

https://doi.org/10.1007/s002540050473

Uaboi-Egbennil, P. O., Okolie, P. N., Martins, O., \& Teniola, O. (2010). Studies on the Occurrence and Distribution of Heavy Metals in Sediments in Lagos Lagoon and Their Effects on Benthic Microbial Population. African Journal of Environmental Science and Technology, 4, 343-351. https://doi.org/10.5897/AJEST09.139

Varol, M., \& Şen, B. (2012). Assessment of Nutrient and Heavy Metal Contamination in Surface Water and Sediments of the Upper Tigris River, Turkey. Catena, 92, 110.

Yang, J., Meng, Z. X., Duan, P. Y., Liu, Z. L., Chen, L., \& Cheng, H. (2014). Spatial Distributions and Sources of Heavy Metals in Sediment from Public Park in Shanghai, the Yangtze River Delta. Applied Geochemistry, 44, 54-60. https://doi.org/10.1016/j.apgeochem.2013.08.007

Zahran, M. A. E., Ahmed, E. Y. A., Elnaggar, A. A., Mohamed, H. A. E., \& El-Alfy, M. A. E. (2015). Assessment and Distribution of Heavy Metals Pollutants in Manzala Lake, Egypt. Journal of Geoscience and Environment Protection, 3, 107-122. https://doi.org/10.4236/gep.2015.36017

Zhan, S., Peng, S., Liu, C., Chang, Q., \& Xu, J. (2010). Spatial and Temporal Variations of Heavy Metals in Surface Sediments in Bohai Bay, North China. Bulletin of Environmental Contamination and Toxicology, 84, 482-734.

https://doi.org/10.1007/s00128-010-9971-6 